\title{
Preliminary results of surgical repair of iatrogenic biliary strictures
}

\author{
Resultados preliminares da correção cirúrgica de estenose cicatricial de vias biliares
}

\author{
Yumi Ricucci Shinkado, Estela Regina Ramos Figueira, Telesforo Bacchella
}

Shinkado YR, Figueira ERR, Bacchella T. Preliminary results of surgical repair of iatrogenic biliary strictures/ Resultados preliminares da correção cirúrgica de estenose cicatricial de vias biliares. Rev Med (São Paulo). 2018 March-Apr.;97(2):116-9.

\begin{abstract}
Introduction: Iatrogenic biliary injury remains a critical complication of cholecystectomy, with devastating consequences to the liver and risk of death. Objective: We aimed to evaluate the long-term results of surgical repair of iatrogenic biliary injuries performed at a single center. Methodology: Patients who underwent surgical reconstruction for iatrogenic biliary injury between 1990 and 2016 were retrospectively evaluated. We collected data from medical records and the electronic database HCMED. The preliminary results were analyzed by comparing frequencies or arithmetic means with standard deviations of the recorded parameters. Results: We included 158 cases in the study, $81 \%$ of these women and with mean age of 45.54 years. The most common symptoms were jaundice $(79.11 \%$ of the cases), abdominal pain $(59.49 \%)$, choluria (52.53\%), acholia/hipocholia (47.47\%), fever (44.3\%), pruritus $(34.18 \%)$ and weight loss $(27.22 \%)$. Biliary stricture was secondary to conventional cholecystectomy in $63.92 \%$ of the cases, laparoscopic cholecystectomy in $22.15 \%$ and nonspecified cholecystectomy in $13.92 \%$. We divided patients according to diagnosis of biliary duct stricture (BDS), $n=93$ cases (58.86\%), and bilioenteric anastomosis stricture (BEAS), $\mathrm{n}=65$ cases $(41.14 \%)$. In BDS group, levels of bilirubin, ALT, AST and GGT were significantly increased pre compared to post surgical repair. In BEAS group, levels of bilirubin, AST and GGT were significantly increased in the preoperative compared to the postoperative, however there were no differences in ALT levels. Recurrence of stricture occurred in 5 cases of BDS group, and 7 cases of BEAS group. Survival in the BDS group was $98.92 \%$ in 1 year and $97.85 \%$ in 5 years, and in BEAS group, $98.64 \%$ and $95.38 \%$, respectively. Conclusions: Surgical repair of complex biliary stricture can achieve long-term success in $89.87 \%$ of patients when performed in reference services.
\end{abstract}

Keywords: Biliary tract diseases/surgery; Postcholecystectomy syndrome/surgery.
RESUMO: Introdução: A estenose cicatricial de vias biliares permanece uma complicação crítica de colecistectomias, com consequências devastadoras para o fígado e risco de morte. Objetivo: Avaliar os resultados a longo prazo da correção cirúrgica de lesão iatrogênica de vias biliares realizada em um único centro. Metodologia: Pacientes submetidos a correção cirúrgica de lesão iatrogênica de vias biliares entre 1990 e 2016 foram avaliados retrospectivamente. As informações foram coletadas dos prontuários e da base de dados eletrônica HCMED. Os resultados preliminares foram analisados pela comparação de frequências ou médias aritméticas com desviopadrão dos parâmetros estudados. Resultados: Foram incluídos 158 casos no estudo, $81 \%$ mulheres e com idade média de 45,54 anos. Os sintomas mais frequentemente apresentados foram icterícia (em 79,11\% dos casos), dor abdominal (59,49\%), colúria $(52,53 \%)$, acolia ou hipocolia fecal $(47,47 \%)$, febre $(44,3 \%)$, prurido $(34,18 \%)$ e perda de peso $(27,22 \%)$. A estenose de vias biliares foi secundária a colecistectomia convencional em $63,92 \%$ dos casos, a colecistectomia laparoscópica em $22,15 \%$, e a colecistectomia não-especificada em $13,92 \%$. Os pacientes foram divididos de acordo com o diagnóstico de estenose de via biliar (EVB), $n=93$ casos $(58,86 \%)$, ou estenose de anastomose bilio-digestiva (EABD), $n=65$ casos $(41,14 \%)$. No grupo EVB, níveis de bilirrubina, ALT, AST e GGT eram significativamente mais altos no pré-operatório que no pósoperatório. No grupo EABD, níveis de bilirrubina, AST e GGT eram significativamente mais altos no pré-operatório que no pós-operatório, entretanto não houve diferenças nos níveis de ALT. Recidiva da estenose ocorreu em 5 casos do grupo EVB, e em 7 casos do grupo EABD. A sobrevida no grupo EVB foi de $98,92 \%$ em 1 ano e $97,85 \%$ em 5 anos; e no grupo EVB, 98,64\% e $95,38 \%$, respectivamente. Conclusões: A correção cirúrgica de lesões complexas de vias biliares tem uma taxa de sucesso de $89,87 \%$ quando realizada em serviços de referência.

Descritores: Doenças biliares/cirurgia; Síndrome póscolecistectomia/cirurgia.

Award Panels Surgical COMU 2017 - XXXVI Congresso Médico Universitário da FMUSP, São Paulo, SP, BR, 6-8 out. 2017.

Disciplina de Cirurgia Digestiva, Departamento de Gastroenterologia, Faculdade de Medicina FMUSP, Universidade de Sao Paulo, São Paulo, SP, BR.Emails: yumi.shinkado@usp.br, estelafigueira@usp.br, bacchell@usp.br.

Correspondence: Yumi Shinkado. Email: yumi.shinkado@usp.br. 


\section{INTRODUCTION}

Riliary duct injury is a severe complication of cholecystectomy, which can occur after surgical manipulation of biliary ducts and lead to decreased life expectancy and quality of life of affected patients ${ }^{1,2}$. The incidence of bile duct injury ranges from $0.1 \%$ to $0.2 \%$ for conventional cholecystectomy, and from 0.3 to $0.5 \%$ for laparoscopic cholecystectomy ${ }^{3-10}$. Several risk factors are implicated in the genesis of biliary duct injury, being the most influential ones acute cholecystitis, obesity and anatomic variations that can induce to error when identifying the cystic duct ${ }^{11}$.

Once the lesion happens, early identification and correct treatment are pivotal in the prognosis of these patients. In approximately $20 \%$ of cases biliary duct injury is detected during the operation, when leaking of bile is seen. In these cases, there is often an attempt to primarily repair the bile duct. In the majority of cases $(80 \%)$, biliary duct injury is only detected during the postoperative period, when the patient presents signs and symptoms compatible with biliary fistula and cholestatic syndrome ${ }^{12,13}$.

Regarding the position of the injury, higher lesions (that is, lesions closer to the hepatic ducts confluence) have higher rates of morbimortality and more complex surgical treatment than lower lesions. Studies performed at Hospital das Clinicas have shown that approximately $50 \%$ of patients with biliary duct injury present high lesions $^{12,14}$.

Treatment of biliary duct injury often requires a multidisciplinary approach. Surgery is currently the method with best results, specially when performed in reference services. A study performed at Hospital das Clínicas by Monteiro da Cunha et al. ${ }^{12}$ showed a $96 \%$ rate of long-term success for surgical correction of low biliary duct injury, and a $77 \%$ rate of long-term success for surgical correction of high biliary duct injury. Endoscopic treatment, which consists in dilatation of the bile duct and placing of prosthesis, is the most common non-surgical treatment for bile duct injury. It is indicated in incomplete sections of the bile duct and less complex cases of stricture, and has a success rate of $77 \%$.

The Department of Pancreatic and Biliary Duct Surgery of Hospital das Clínicas is a reference service for treatment of biliary duct injury. In 1986, Machado et al. ${ }^{15}$ published the technique for correcting high lesions of biliary duct, which is used to this day and even then presented promising results ${ }^{16}$. Patients referred to Hospital das Clínicas have often already been submitted to surgical or endoscopic treatment with poor results, and frequently present complications as repeated episodes of cholangitis and hepatic injury.

The objective of our study was to evaluate the long-term results of surgical repair of such complex iatrogenic biliary injuries in a single center.

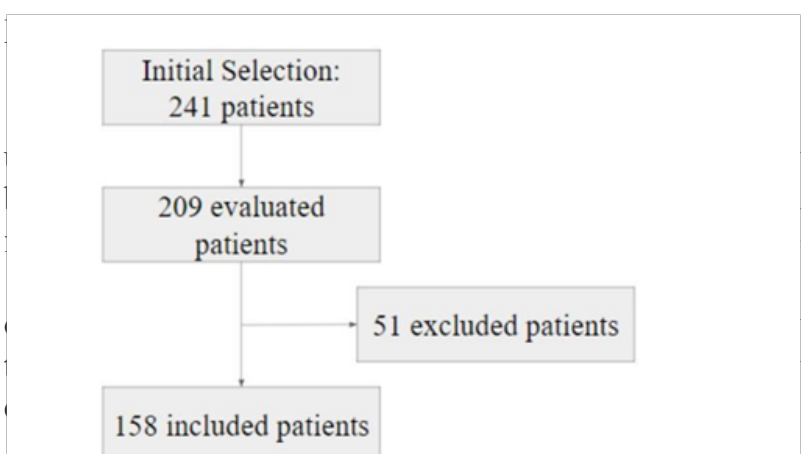

Figure 1. Patient selection flowchart

Patient's data was collected from medical records and the electronic database HCMED. The preliminary results were analyzed by comparing frequencies or arithmetic means with standard deviations of the recorded parameters.

\section{RESULTS}

We included 158 cases in the study, $81 \%$ of these women and with mean age of 45.54 years. The most commonly presented symptoms were jaundice in $79.11 \%$ of the cases, abdominal pain in $59.49 \%$, choluria in $52.53 \%$, acholia/hipocholia in $47.47 \%$, fever in $44.3 \%$, pruritus in $34.18 \%$ and weight loss in $27.22 \%$.

Biliary stricture was secondary to conventional cholecystectomy in $63.92 \%$ of the cases, laparoscopic cholecystectomy in $22.15 \%$ and non-specified cholecystectomy in $13.92 \%$. Regarding Bismuth's classification of bile duct injury (Figure 2), 17 patients $(10.76 \%)$ presented lesion classified as B1, $61(38.61 \%)$ as $\mathrm{B} 2,61(38.61 \%)$ as B3, $16(10.13 \%)$ as B4 and $4(2.53 \%)$ were impossible to be classified with the available data.

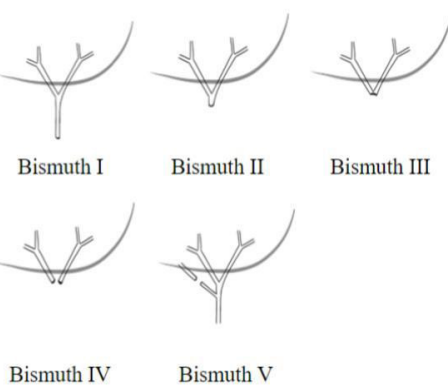

Figure 2. Bismuth's classification for bile duct injury

We divided patients according to diagnosis of biliary duct stricture (BDS), $n=93$ cases $(58.86 \%)$, and 
bilioenteric anastomosis stricture (BEAS), $n=65$ cases $(41.14 \%)$. The BEAS group consisted of patients who had already been submitted to an attempt of surgical correction of iatrogenic biliary injury in other service, but had a recurrence in the biliary stricture and were then referred to Hospital das Clínicas.
In BDS group, levels of bilirubin, ALT, AST and GGT were significantly increased pre compared to post surgical repair (Table 1). In BEAS group, levels of bilirubin, AST and GGT were significantly increased in the preoperative compared postoperative; however there were no differences in ALT levels (Table 1).

Table 1. Comparison of results pre and post surgical repair in bile duct stricture (BDS) group and bilioenteric anastomosis stricture (BEAS) group

\begin{tabular}{llccc}
\hline & & Preoperative & Postoperative & P value \\
\hline \multirow{5}{*}{ BDS group } & $5.42 \pm 7.72$ & $1.10 \pm 2.04$ & 0.0023 \\
& Bilirubin, mg/dL & $68.84 \pm 55.64$ & $33.23 \pm 29.37$ & 0.0026 \\
& AST, UI/L & $90.61 \pm 98.76$ & $37.63 \pm 42.24$ & 0.0055 \\
& ALT, UI/L & $392.6 \pm 327.1$ & $193.5 \pm 264.7$ & 0.0046 \\
\hline \multirow{5}{*}{ BEAS group } & GGI/L & $5.20 \pm 6.51$ & $2.78 \pm 6.77$ & 0.0488 \\
& Bilirubin, mg/dL & $77.84 \pm 63.47$ & $55.73 \pm 61.74$ & 0.0413 \\
& AST, UI/L & $79.10 \pm 64.44$ & $61.61 \pm 77.62$ & 0.1004 \\
& GGT, UI/L & $498.1 \pm 452.2$ & $292.1 \pm 378.0$ & 0.0003 \\
\hline
\end{tabular}

Recurrence of stricture occurred in 5 cases of BDS group (5.38\%), submitted again to surgical repair, and in 7 cases of BEAS group (10.77\%), 4 submitted to surgical repair and 3 referred to the Liver Transplant Unit. Survival in the BDS group was $98.92 \%$ in 1 year and $97.85 \%$ in 5 years, and in BEAS group $98.64 \%$ and $95.38 \%$, respectively (Figure 3 ).

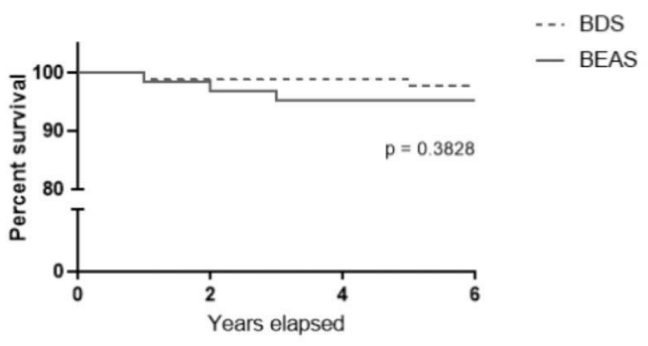

Figure 3. 5-year patient survival after correction of biliary stricture

\section{DISCUSSION}

The epidemiology of patients submitted to surgical repair of iatrogenic biliary injury is compatible with that of patients who undergo cholecystectomy, in other words, there is a predominance of adult women in both procedures. The symptoms most commonly presented are also consistent with cholestatic syndrome, as was expected.

Contrary to what is described in literature, we have found a higher prevalence in biliary duct injury caused by conventional cholecystectomy, instead of secondary to laparoscopic cholecystectomy. The conclusions we can draw from this finding are very limited, as this type of study is not adequate to analyze prevalence.

We observed a predominance of higher biliary lesions, with $77.22 \%$ of the cases classified as B2 and B3. As was already mentioned, high lesions have more complex treatment. The prevalence of such lesions, then, confirms the position of Hospital das Clinicas as a reference service.

There was a significative decrease in all laboratorial parameters analyzed in BDS group, and in all but ALT in BEAS group. This poorer result in BEAS group can be due to delayed treatment and longer exposure of the liver to lesion. We observe, concordantly, that the rate of recurrence in the BEAS group was twice the rate at BDS group, and that in this first group, 3 patients had to be referred to the Liver Transplant Unit. There was no difference in survival between the groups.

\section{CONCLUSION}

Surgical repair of complex biliary stricture can achieve long-term success in $89.87 \%$ of patients when performed in reference services.

\section{REFERENCES}

1. Flum DR, Cheadle A, Prela C, Dellinger EP, Chan L. Bile duct injury during cholecystectomy and survival in medicare beneficiaries. JAMA. 2003;290(16):2168-73. doi: 10.1001/jama.290.16.2168.

2. Boerma D, Rauws EA, Keulemans YC, et al. Impaired quality of life 5 years after bile duct injury during 
laparoscopic cholecystectomy: a prospective analysis. Ann Surg. 2001;234(6):750-7. Available from: https:// www.ncbi.nlm.nih.gov/pmc/articles/PMC1422134/.

3. Deziel DJ, Millikan KW, Economou SG, Doolas A, Ko ST, Airan MC. Complications of laparoscopic cholecystectomy: a national survey of 4,292 hospitals and an analysis of 77,604 cases. Am J Surg. 1993;165(1):9-14. https://doi.org/10.1016/S0002-9610(05)80397-6.

4. Vecchio R, MacFadyen BV, Latteri S. Laparoscopic cholecystectomy: an analysis on 114,005 cases of United States series. Int Surg. 1998;83(3):215-9.

5. Adamsen S, Hansen OH, Funch-Jensen P, Schulze S, Stage JG, Wara P. Bile duct injury during laparoscopic cholecystectomy: a prospective nationwide series. J Am Col Surg. 1997;184(6):571-8.

6. Nuzzo G, Giuliante F, Giovannini I, Ardito F, D’Acapito F, Vellone M, Murazio M, Capelli G. Bile duct injury during laparoscopic cholecystectomy: results of an Italian national survey on 56591 cholecystectomies. Arch Surg. 2005;140(10):986-92. doi: 10.1001/archsurg.140.10.986.

7. Harboe KM, Bardram L. The quality of cholecystectomy in Denmark: outcome and risk factors for 20,307 patients from the national database. Surg Endosc. 2011;25(5):163041. doi: 10.1007/s00464-010-1453-8.

8. Waage A, Nilsson M. Iatrogenic bile duct injury: a population-based study of 152776 cholecystectomies in the Swedish Inpatient Registry. Arch Surg. 2006;141(12):120713. doi: 10.1001/archsurg.141.12.1207.

9. A prospective analysis of 1518 laparoscopic cholecystectomies. The Southern Surgeons Club.
New Engl J Med. 1991;324(16):1073-8. doi: 10.1056/ NEJM199104183241601.

10. Tantia O, Jain M, Khanna S, Sen B. Iatrogenic biliary injury: 13,305 cholecystectomies experienced by a single surgical team over more than 13 years. Surg Endosc. 2008;22(4):1077-86. doi: 10.1007/s00464-007-9740-8.

11. Jablonska B, Lampe P. Iatrogenic bile duct injuries: etiology, diagnosis and management. World J Gastroenterol. 2009;15(33):4097-104. doi: 10.3748/ wjg. 15.4097.

12. Monteiro da Cunha JE, Machado MC, Herman P, Bacchella T, Abdo EE, Penteado S, Jukemura J, Montagnini A, Machado MA, Pinotti HW. Surgical treatment of cicatricial biliary strictures. Hepatogastroenterology. 1998;45(23):1452-6.

13. Wu JS, Peng C, Mao XH, Lv P. Bile duct injuries associated with laparoscopic and open cholecystectomy: sixteen-year experience. World J Gastroenterol. 2007;13(16):2374-8. doi: 10.3748/wjg.v13.i16.2374.

14. Chapman WC, Halevy A, Blumgart LH, Benjamin IS. Postcholecystectomy bile duct strictures. Management and outcome in 130 patients. Arch Surg. 1995;130(6):597-602; discussion 602-594. doi: 10.1001/ archsurg.1995.01430060035007.

15. Machado MC, da Cunha JE, Bacchella T. A modified technique for surgical repair of cicatricial stenosis of the bile duct. Surg Gynecol Obstetr. 1986;162(3):282-4.

16. Abdo EE, Machado MC, da Cunha JE, Bacchella T, Pinotti HW. Estenose cicatricial do hepatocolédoco. Estudo de 67 casos. Rev Hosp Clin. 1986;41(6):267-73. 